\title{
The role of protected areas in representing aquatic biodiversity: a test using $\alpha, \beta$ and $\gamma$ diversity of water beetles from the Segura River Basin (SE Spain)
}

\author{
J. M. Zamora-Marín ${ }^{1, *}$, C. Gutiérrez-Cánovas ${ }^{2,3}$, P. Abellán ${ }^{4}$ and A. Millán ${ }^{2}$
}

${ }^{1}$ Departamento de Zoología y Antropología Física, Universidad de Murcia, 30100 Campus de Espinardo, Murcia, Spain.

${ }^{2}$ Departamento de Ecología e Hidrología, Universidad de Murcia, 30100 Campus de Espinardo, Murcia, Spain.

${ }^{3}$ Catchment Research Group, Cardiff University. School of Biosciences, The Sir Martin Evans Building, Museum Avenue, Cardiff CF10 3AX, UK.

${ }^{4}$ Department of Biology, Queens College, City University of New York, 65-30 Kissena Blvd Flushing, New York, NY 11367, USA.

*Corresponding author: josemanuel.zamora@um.es

Received: 25/08/2015

Accepted: 01/12/2015

\begin{abstract}
The role of protected areas in representing aquatic biodiversity: a test using $\alpha, \beta$ and $\gamma$ diversity of water beetles from the Segura River Basin (SE Spain)

Networks of protected areas represent one of the main strategies to reduce the rapid loss of biodiversity. However, most of these protected areas have been designed by considering only charismatic groups of vertebrates and plants, most linked to terrestrial environments. Thus, little is known about how well protected areas perform in representing aquatic biodiversity. This study analyses the suitability of national and European protected area networks (Natural Protected Areas and Natura 2000 ) in representing such biodiversity. For this purpose, we studied the different components of diversity ( $\alpha, \beta$ and $\gamma$ ) using water beetles from the Segura River Basin as surrogates of overall macroinvertebrate biodiversity. Our results revealed no significant differences in $\alpha$-diversity between protected and non-protected areas. Similarly, we did not find significant differences in $\beta$-diversity components (species replacement and nestedness, i.e., differences in among-site richness without species replacement) between protected and non-protected areas. The species replacement contributed more than nestedness to explain overall $\beta$-diversity changes. Finally, we found that the $\gamma$-diversity component was significantly higher in both protected areas, when compared to an equivalent number of randomly selected locations.

Thus, the protected area networks from the Segura River Basin currently seem to have gaps in embracing the different aquatic biodiversity components. These results for river management and biodiversity conservation are discussed, providing some guidelines for future research.
\end{abstract}

Key words: Biodiversity conservation, macroinvertebrates, aquatic ecosystems, protected areas.

\section{RESUMEN}

El papel de las áreas protegidas para representar la biodiversidad acuática: un test utilizando la diversidad $\alpha, \beta$ y $\gamma$ de los coleópteros acuáticos en la cuenca del Segura (SE España)

Las redes de áreas protegidas representan una de las principales estrategias para reducir la pérdida de biodiversidad. Sin embargo, muchas de estas áreas han sido diseñadas considerando únicamente grupos carismáticos mayoritariamente terrestres, como los vertebrados y las plantas. Por lo tanto, existe un escaso conocimiento sobre la capacidad de las áreas protegidas para representar la biodiversidad acuática. Este trabajo analiza la idoneidad de las redes nacionales y europeas de áreas protegidas (Espacios Naturales Protegidos y Red Natura 2000) para representar dicha biodiversidad. Para ello, estudiamos los diferentes componentes de la diversidad $(\alpha, \beta$ y $\gamma$ ) utilizando los coleópteros acuáticos de la cuenca del río Segura como indicadores de la biodiversidad total de macroinvertebrados. Nuestros resultados no muestran diferencias significativas en la diversidad a entre áreas protegidas y no protegidas. Del mismo modo, no encontramos diferencias sig- 
nificativas en los componentes de la diversidad $\beta$ (reemplazamiento y anidamiento, i.e., diferencias en la riqueza entre localidades sin que tenga lugar recambio de especies) entre áreas protegidas y no protegidas. El reemplazamiento de especies contribuyó más que el anidamiento en los cambios observados en la diversidad $\beta$ total. Finalmente, encontramos que las dos redes de áreas protegidas mostraron una diversidad $\gamma$ mayor, en comparación con un número equivalente de localidades seleccionadas al azar.

Por lo tanto, las redes de áreas protegidas de la cuenca del río Segura parecen presentar actualmente algunas lagunas a la hora de abarcar los diferentes componentes de la biodiversidad. Por último, discutimos las implicaciones de estos resultados en la gestión y conservación de los ríos, proporcionando algunas directrices para futuras investigaciones.

Palabras clave: Conservación de la biodiversidad, macroinvertebrados, ecosistemas acuáticos, espacios protegidos.

\section{INTRODUCTION}

During the last several decades, the need to reduce the rapid loss of biodiversity has fostered the important development of conservation efforts for both species and habitats. In Spain, the national network of protected areas is complemented by a network of protected areas proposed by the European Union through the Natura 2000 network. Despite these advances, most of these protected areas have been designed by considering only charismatic groups of vertebrates and plants, most linked to terrestrial environments. However, inland water bodies are recognized as biodiversity hotspots (Strayer \& Dudgeon, 2010) and are one of the most threatened ecosystems on the planet (Monroe et al., 2009; Geist, 2011). Within these systems, macroinvertebrates represent the highest percentage of aquatic biodiversity (Balian et al., 2008) and are crucial for an important number of ecosystem processes; i.e., they perform key ecosystem functions, such as those related to the decomposition of plant detritus (Gessner et al., 1999) or organic matter transfer to higher trophic levels such as fish or river birds (e.g., Ormerod et al., 1988). Furthermore, aquatic macroinvertebrates are a management concern because they are widely used to monitor the ecological status of water bodies (Bonada et al., 2006). Unfortunately, little is known about how well protected areas perform in representing aquatic macroinvertebrates (Herbert et al., 2009). Efforts to conserve aquatic ecosystem biodiversity are often non-existent or ineffective, resulting in few specific reserves created to protect aquatic biota (Saunders et al., 2002).
The Iberian Peninsula is widely recognized as holding a great diversity of aquatic ecosystems, including a high number of species and endemic taxa (e.g., Sánchez-Fernández et al., 2008a; Abellán \& Svenning, 2013). The conservation of these ecosystems should be a priority, especially considering the fact that they are experiencing a wide array of human impacts (Prenda et al., 2006). The situation is particularly critical in areas where irrigation crops are growing and replacing natural and semi-natural lands, such as the Iberian southeast (Sánchez-Fernández et al., 2004, 2008a; Millán et al., 2006, 2011; Abellán et al., 2007; Bruno et al., 2014). As an example, in the Segura River Basin, the water demand for irrigation and urban development exceeds the renewable water resources available by approximately two-fold (Zimmer, 2010).

There are many criteria that can help identify and prioritize areas or ecosystems with high conservation interest, and species diversity is one of the most widely used criteria for this purpose. Diversity can be partitioned into three different components: $\alpha, \beta$ and $\gamma$ diversity (Whittaker, 1960; Odum \& Warrett, 2006). The fraction of diversity observed in a particular habitat at a given time is called $\alpha$-diversity. The differences in species composition between sites is referred to as $\beta$-diversity. Furthermore, $\beta$-diversity can be subpartitioned into two components (Baselga, 2010): turnover and nestedness. Turnover explains the differences in community composition due to species replacement, whilst the nestedness-resultant component accounts for the changes in species richness not related with turnover (for details, see Baselga, 2010). Turnover in- 
volves replacing certain species due mainly to biotic, environmental or historical restrictions (Qian et al., 2005; Baselga, 2010), while nestedness occurs when the biotas of sites with smaller numbers of species are subsets of the biotas at richer sites (Ulrich et al., 2009). The nestedness component can reflect non-random processes of species loss due to ordered environmental sorting or dispersal limitation (Ulrich et al., 2009). Finally, $\gamma$-diversity represents the regional species pool (i.e., cumulative species richness considering all habitats together), reflecting a combination of $\alpha$ and $\beta$ diversities.

The use of biodiversity surrogates allows the study of biodiversity patterns using a subset of the community that accurately represents the general patterns of the whole community for a given ecosystem type (Pearson, 1994). This approach is highly interesting in conservation biology because it reduces the great effort required to sample and identify all taxa to species level, especially when studying high diversity communities such as aquatic macroinvertebrates. In this sense, water beetles have been shown as excellent indicators of overall macroinvertebrate biodiversity in different regions (Bilton et al., 2006; Guareschi et al., 2012). Notably, several studies conducted in the Segura River Basin (e. g, Sánchez-Fernández et al., 2004; Millán et al., 2006; Abellán et al., 2007; Bruno et al., 2012) have used water beetle species as biodiversity surrogates to identify hotspots and potential gaps in the network of protected areas. However, none of these studies addressed the suitability of protected areas to represent the $\alpha, \beta$ and $\gamma$-diversity components of aquatic biodiversity.

Here, we used water beetles as biodiversity surrogates to evaluate the role of national and European-designated protected areas in representing different facets of aquatic biodiversity. More specifically, the objectives of this study were: (i) to determine whether species richness at the site scale ( $\alpha$-diversity) is higher in protected areas than in non-protected areas; (ii) to explore if protected areas have a higher overall multisite $\beta$-diversity and turnover in comparison with non-protected areas; (iii) to know to what extent the compositional differences between protected and unprotected communities are explained by the effect of nestedness; and (iv) to evaluate whether networks of protected areas harbour more overall diversity ( $\gamma$-diversity) than that expected by chance, given their area.

If we consider that protected areas should perform well in accounting for these three facets of biodiversity, we can predict that: (i) sampling sites included in protected areas will show greater mean local richness than non-protected localities; (ii) $\beta$-diversity and turnover will be greater within protected areas than in an equivalent set of random localities; (iii) the compositional changes between the species pools of protected and unprotected areas will mainly be the result of nestedness-resultant dissimilarities; and (iv) the species pool of the protected areas will be greater than the pool occurring at an equivalent set of random localities.

\section{MATERIAL AND METHODS}

\section{Study area}

The Segura River Basin is located in the southeast of the Iberian Peninsula, occupying an area of $18815 \mathrm{~km}^{2}$ (see Fig. 1). It is characterized by a Mediterranean climate, with hot and dry summers, cycles of droughts and sporadic flashfloods caused by torrential rains (see Belmar et $a l$., 2013 for details). There is also a predominance of fluvial systems, as opposed to standing waters. Headwater mountain streams are characterized by their low mineral contents and permanent flows. Lowland streams show a higher degree of flow intermittence, mineralization and/or nutrient enrichment (Vidal-Abarca et al., 1992; Millán et al,. 2006; Abellán et al., 2007; Belmar et al., 2013). The mineralized nature of some waters is due to the predominance of soluble materials of geological origin, such as halites (Millán et al., 2011). Organic pollution and nutrient enrichment are caused by agricultural intensification, especially by irrigated crops (Bruno et al., 2014). Due to the arid conditions, crops require an important amount of water, which is usually extracted from flowing waters or aquifers. Wa- 
ter extraction reduces flows, causing a reversal of typical hydrological behaviour (more discharge in summer) and diffuse pollution (Belmar et al., 2013). Despite those impacts, there are a considerable number of water bodies in good ecological condition (Díaz et al., 2008), which allows the study of biodiversity patterns between sites and subsets (e.g., sites within protected areas vs sites within non-protected areas).

\section{Species inventory}

Water beetles sensu Jäch \& Balke (2008) were used as surrogates of overall macroinvertebrate biodiversity. Information on species distribution was obtained from the "AE-Biodiversity" database, which contains biological and environ- mental records compiled by the Aquatic Ecology research team at the University of Murcia, and collected by the senior author of this paper and collaborators from the early 80s to the present day (e.g., Millán, 1991; Sánchez-Fernández et al., 2008a; Sánchez-Fernández et al., 2008b). The "AE-Biodiversity database" includes water beetle records from approximately 2600 sampling sites in the Iberian Peninsula and other surrounding areas across the western Mediterranean. Approximately 800 of these localities are found within the study area.

Water beetle samples were generally obtained using an entomological D-hand net with a $0.5 \mathrm{~mm}$ mesh size and following a multihabitat protocol. On average, the sampling effort varied between 30 and 60 minutes, depending on

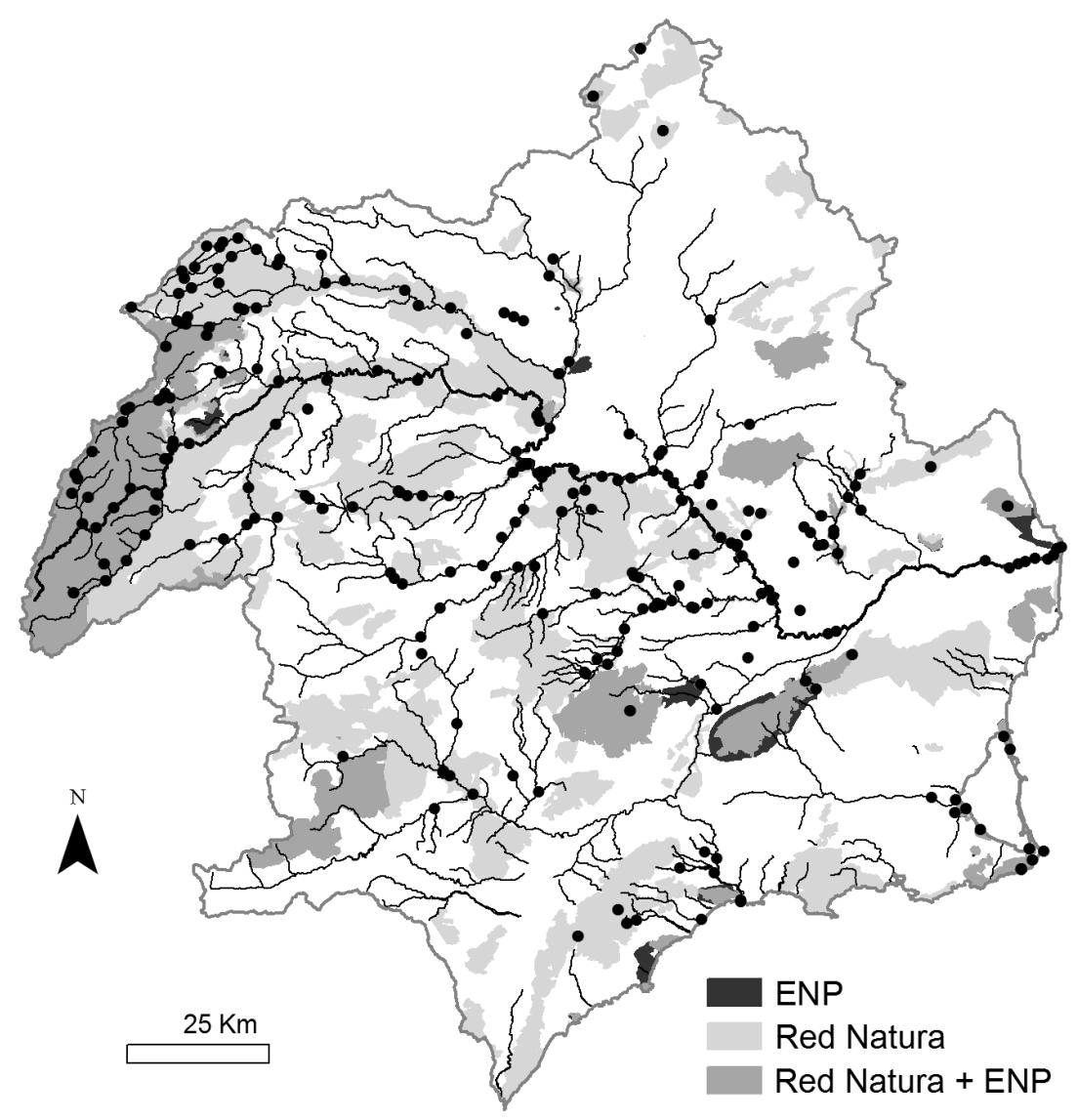

Figure 1. Location of the selected sampling sites from the Segura Basin showing the protected area networks. Ubicación de los puntos de muestreo seleccionados en la cuenca del Segura, mostrando las redes de áreas protegidas. 
the complexity of the prospected locality. The samples were preserved in $75-96 \%$ ethanol and subsequently identified in the laboratory. We selected sampling locations that contained at least one sample collected during the summer, a period in which organisms are more active and concentrated due to discharge reduction, making easier to capture more species (Millán et al., 2014). From this subset, up to two samples were chosen per locality, one showing the higher richness for summer and other showing the higher richness within the remaining samples. When two samples were available, they were pooled, resulting in one species list per location. We finally selected 256 sampling localities (Fig. 1), compiling the variety of water bodies present in the study area (Abellán et al., 2007).

\section{Protected areas}

We considered two different protected area networks in the Segura River Basin: (a) Protected Areas (PA) classified under the national and autonomous Spanish legislation; and (b) the Natura 2000 network (N2000), which represents a key tool for biodiversity conservation at the European scale and aims to guarantee the long-term survival of Europe's most valuable and threatened species and habitats. N2000 includes Special Areas of Conservation (SACs) designated under the Habitats Directive (92/43/EC) and Special Protection Areas (SPAs), which are designated under the Birds Directive (79/409/EC, 2009/147/EC). GIS data layers supplied by the Spanish National Conservation Agency were edited and combined to produce a single layer of PA and N2000, which was used to classify the selected sampling sites within and outside protected areas (see Fig. 1).

According to the distribution of sampling sites (i.e., within and outside protected areas), localities were assigned to three categories: PA sites (those localities within areas designated as Protected Areas); PA + N2000 sites (those localities within areas designated as PA or N2000), and NP (non-protected) sites (those localities not included within any of the protected areas). The NP category covers a heterogeneous set of sites in terms of ecological integrity, ranging from almost pristine sites to those showing high agricultural or urban intensification (e.g., Díaz et al., 2008; Bruno et al., 2014). Finally, our dataset contained a total of 46 PA sites, 118 PA + N2000 sites, and 138 NP sites. To our knowledge, no significant environmental changes were detected in any of the selected sites during the studied period.

\section{Data analysis}

Values describing the different components of water beetle diversity ( $\alpha, \beta$ and $\gamma$ ) were calculated for sites located within and outside protected areas. First, the $\alpha$-diversity was calculated as the species richness in each sampling site. An analysis of variance (ANOVA) was used to test if the $\alpha$-diversity (species richness) differed among PA, PA+N2000 and NP sites. Due to the lack of normality and homogeneity of variance in the residuals of the model, and the unbalanced design, alpha was set to 0.001 to minimize the possibility of finding false positives. Post-hoc analyses were conducted using a modified version of Student's t-test, which is robust against the non-normality, heteroscedasticity and unbalanced data (Herberich et al., 2010).

Second, following Baselga (2010), $\beta$-diversity components were measured within each set of sites as both the spatial turnover in species composition ( $\beta_{\text {SIM }}$, Simpson's dissimilarity) and dissimilarity associated with species loss that produces nested assemblages $\left(\beta_{\text {sne }}\right.$, nestednessdriven dissimilarity). It should be noted that $\beta_{\text {sne }}$ is not a measure of nestedness in absolute terms, but a measure of the dissimilarity between communities due to the effect of nested patterns (Baselga, 2010). The sum of these two components was overall $\beta$-diversity $\left(\beta_{\text {SOR }}\right.$, Sørensen's dissimilarity). Then, whether protected areas have higher $\beta$-diversity than expected by chance given the included number of sites was explored. For this purpose, we estimated the $\beta$-diversity and its components within each protected area network and compared them to expected values from 999 random draws of an equal number of sites, taken from the pool of sampled sites (including both protected and unprotected areas). The proportion of random samples with higher 
diversity values than those observed for the protected area networks allowed us to obtain a significant value (alpha set as 0.05).

In addition, we assessed to what extent the compositional differences between protected and unprotected communities are due to the effect of nested patterns (i.e., the percentage of overall dissimilarity explained by the nestednessresultant component when comparing the species pools included in unprotected and protected areas; PA and PA + N2000). For this purpose, the ratio $\beta_{\text {sne }}: \beta_{S O R}$ (hereafter ' $\beta_{\text {ratio }}$ ') was calculated among the sites in each protected areas network and at an equivalent number of NP randomly selected sites. This procedure was repeated to create 999 comparisons for each protected area network (i.e., PA vs. NP and PA+N2000 vs. NP). In order to know the sense of the nestedness process, the $\beta_{\text {ratio }}$ was multiplied by -1 when the species pool of the subset of localities from unprotected areas was greater than the species pool estimated for the protected areas. Otherwise, it was multiplied by +1 . Values of the $\beta_{\text {ratio }}$ between 0.0 and 0.5 (or between -0.5 and
$0.0)$ indicate that the $\beta$-diversity was mainly determined by species turnover, whereas values between 0.5 and 1.0 (or between -1.0 and -0.5 ) reveal a greater contribution of nestedness to the total $\beta$-diversity. Obviously, values around \pm 0.5 would represent a balanced contribution of turnover and nestedness to the $\beta$-diversity. For this purpose, we finally compared the distributions of the $\beta_{\text {ratio }}$ values calculated for PA-NP and $\mathrm{PA}+\mathrm{N} 2000-\mathrm{NP}$ to test which protected area network best represents the species occurring in NP areas. Again, a modified version of Student's $\mathrm{t}$-test was used because it is robust against nonnormality, heteroscedasticity and unbalanced data (Herberich et al., 2010).

Third, the $\gamma$-diversity of each protected area was calculated as the total species richness found in sites within the whole network (PA and PA + N2000 sites, respectively). Then, the effectiveness of each network of protected areas in gathering the $\gamma$-diversity was tested by comparing the total species richness within a given network with what would be expected by chance, given the number of sites it covers. To do this, we again

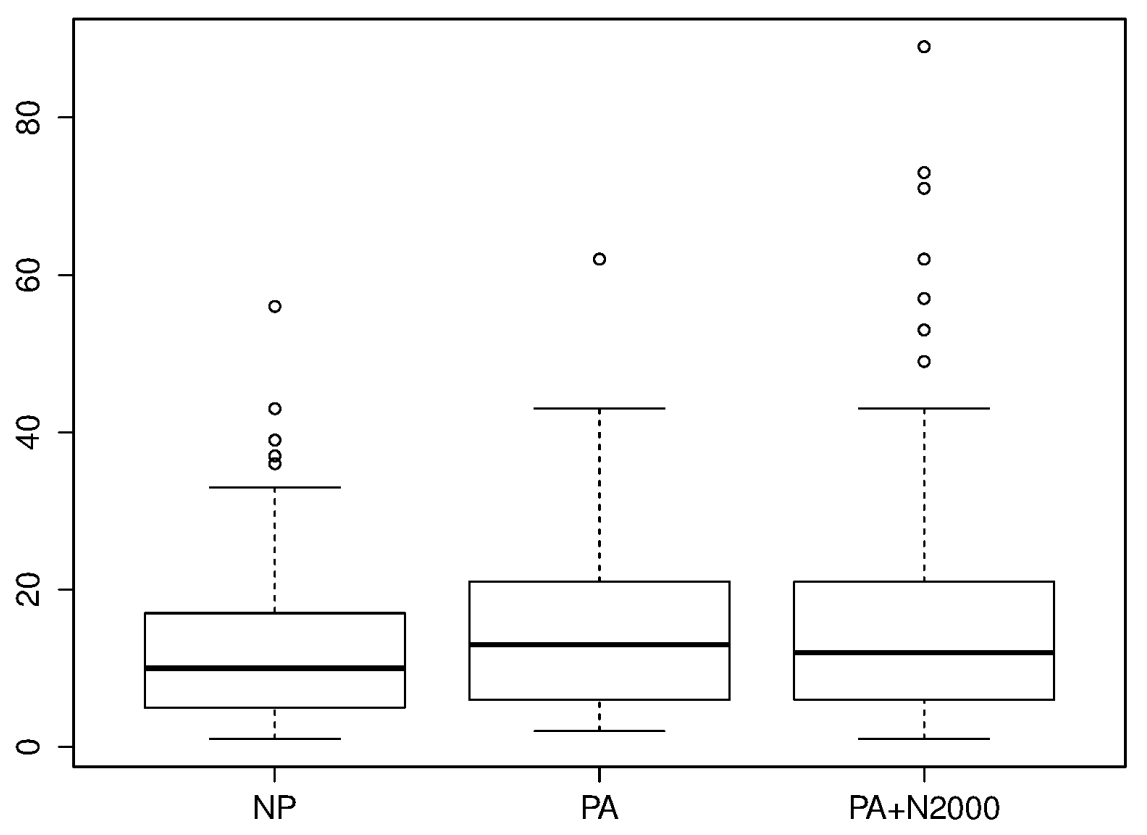

Figure 2. Boxplot showing the $\alpha$-diversity values for sites included in NP, PA and PA + N2000. NP: non-protected areas; PA: protected areas; N2000: Natura 2000 network. Diagrama de caja donde se muestran los valores de diversidad alfa en localidades incluidas en NP, PA y PA + N2000. NP: áreas no protegidas; PA: áreas protegidas; N2000: red Natura 2000. 
Table 1. Comparison of the $\beta$-diversity in sampling sites within and outside protected areas. SIM: dissimilarity due to species turnover; SNE: nestedness-resultant dissimilarity; SOR: dissimilarity due to overall compositional changes $(\beta$-diversity). NP: non-protected areas; PA: protected areas; N2000: Natura 2000 network. Comparación de la diversidad $\beta$ en puntos de muestreo dentro y fuera de las áreas protegidas. SIM: disimilitud debida al reemplazamiento de especies, SNE: disimilitud resultante del anidamiento; SOR: disimilitud debida a los cambios de composición general (diversidad $\beta$ ). NP: áreas no protegidas; PA: áreas protegidas; N2000: red Natura 2000.

\begin{tabular}{ccccc}
\hline & \multicolumn{2}{c}{ PA vs random } & \multicolumn{2}{c}{ PA + N2000 vs random } \\
Component & $z$-score & $p$-value & $z$-score & $p$-value \\
\hline SIM & 0.73 & 0.447 & -0.61 & 0.525 \\
SNE & -0.73 & 0.441 & 0.57 & 0.547 \\
SOR & 0.11 & 0.915 & -0.42 & 0.691 \\
\hline
\end{tabular}

compared the observed $\gamma$-diversity to the expected values from 999 random draws of an equal number of sites taken from the total pool of sampling sites. The statistical significance of each comparison (alpha set as 0.05) was obtained through a bilateral analysis of each distribution with respect to the $\gamma$-diversity observed within each protected area network.

All analyses were performed using R ( R Development Core Team, 2010), and the $\beta$-diversity metrics were obtained with R package "Betapart" (Baselga \& Orme, 2012).

\section{RESULTS}

A total of 211 species of true water beetles were recorded in the whole set of studied localities. Among them, 163 were found in PA sites, 201 in PA + N2000 sites, and 171 in NP sites. Only ten species were not detected in any of the protected areas. Twenty species occurring within PA were not recorded in $\mathrm{N} 2000$, and 39 species included in N2000 were not found in PA. Overall, the N2000 network contained 21 more species than the set of PA sites.

The values of the $\alpha$-diversity showed no significant differences at $\alpha=0.001$ among the ar-
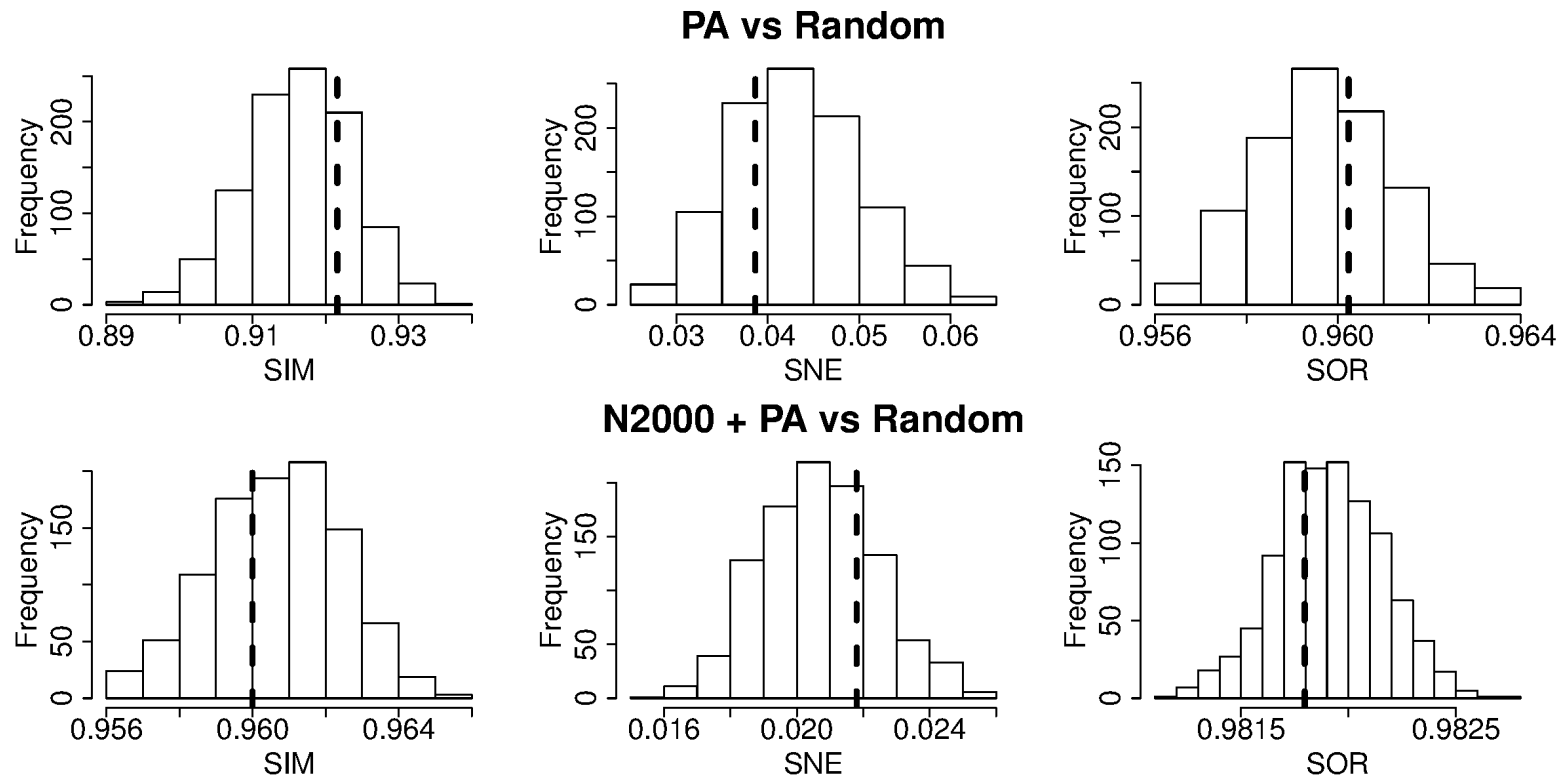

Figure 3. Comparison between the $\beta$-diversity and its components estimated for each protected area network (dashed lines) and for an equivalent number of randomly selected sites (histogram values). SIM: dissimilarity due to species turnover; SNE: nestednessresultant dissimilarity; SOR: dissimilarity due to overall compositional changes ( $\beta$-diversity).NP: non-protected areas; PA: protected areas; N2000: Natura 2000 network. Comparación entre la diversidad $\beta$ y sus componentes estimados para cada red de áreas protegidas (líneas discontinuas) y para un número equivalente de localidades seleccionadas aleatoriamente (valores de histograma). SIM: disimilitud debida al reemplazamiento de especies; SNE: disimilitud resultante del anidamiento; SOR: disimilitud debida a los cambios de composición general (diversidad $\beta$ ). NP: áreas no protegidas; PA: áreas protegidas; N2000: red Natura 2000. 
eas compared $(F$-value $=3.18, p$-value $=0.043$, see Materials and Methods). The average number of species that occurred in the localities from the different areas ranged from approximately 12 to 17 species (Fig. 2). The post-hoc analysis revealed non-significant differences between NP and $\mathrm{PA}+\mathrm{N} 2000(t$-value $=2.33 ; p$-value $=0.052)$.

We observed that turnover, nestedness and total $\beta$-diversity estimated within PA and PA + N2000 did not differ from the simulated values estimated for an equivalent number of random localities (Table 1, Fig. 3). These results also show that the observed $\beta$-diversity values within protected areas were mainly driven by turnover $\left(\beta_{S I M}=0.922\right.$ and 0.959 for PA and PA $+\mathrm{N} 2000$, respectively), with only a small contribution from nestedness $\left(\beta_{S N E}=0.380\right.$ and $\beta_{S N E}=0.218$, respectively).

The $\beta_{\text {ratio }}$ values for the combined pools of each protected areas network (PA and PA + N2000) and an equivalent number of NP localities taken at random were distributed, approximately, between -0.20 and 0.90 , with the more frequent values of approximately 0.50 in both cases (Fig. 4). These results indicate similar con- tributions of turnover and nestedness-resultant components to the overall $\beta$-diversity, as well as that species pools in protected sites were usually richer than those in random NP sites (as observed by the positive values, see Materials and Methods for more details). When comparing both distributions, the obtained values of the $\beta_{\text {ratio }}$ for PA $+\mathrm{N} 2000$ sites vs. NP were significantly higher than those for PA sites vs. NP (estimate: 0.04 ; $\mathrm{t}:-6.82$; $p$-value $<0.001$ ). This result indicates a higher capacity of PA + N2000 sites to represent the species pool of NP sites.

The $\gamma$-diversity values of PA sites were significantly higher than those estimated for a number of equivalent random sites $(z$-score $=3.58$; $p$-value $<0.001$; Fig. 5). The $\gamma$-diversity values of PA + N2000 sites were also significantly higher than those simulated $(z$-score $=11.19$; $p$-value $<0.001)$.

\section{DISCUSSION}

Our results suggest that national or European protected areas do not perform better in rep-
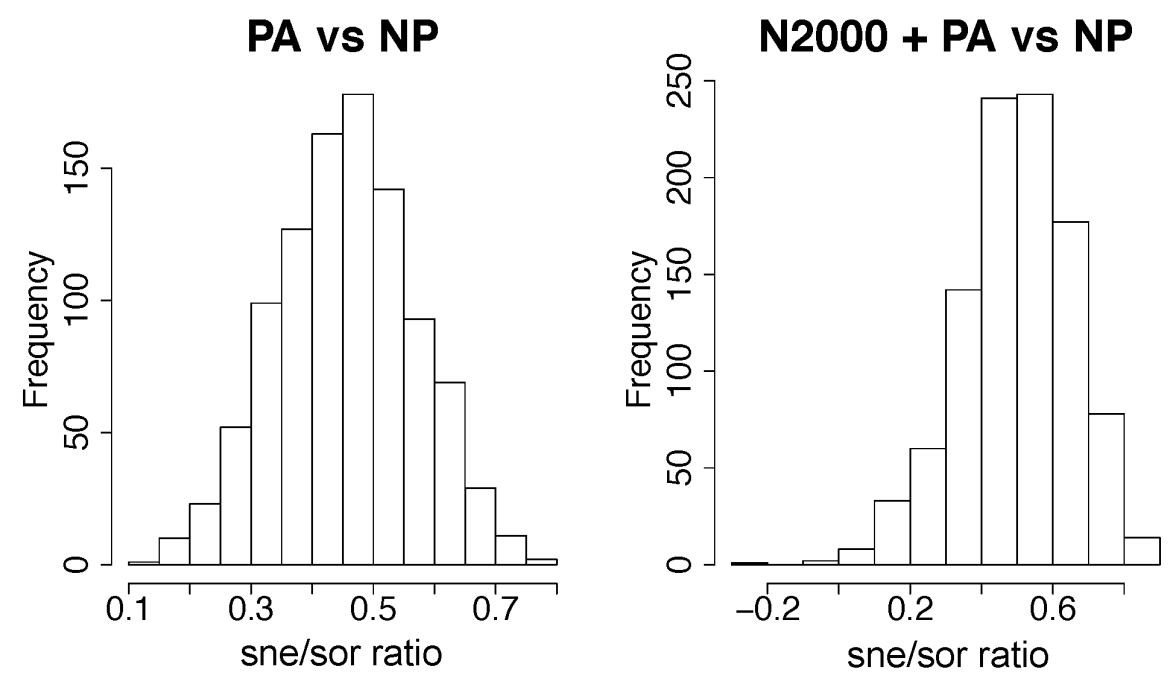

Figure 4. Distribution of the estimated values of the $\beta_{\text {ratio }}$ (sne/sor ratio) for combined pools containing the species occurring in each protected network (PA and PA + N2000, respectively) and the species of an equivalent number of NP sites, selected randomly. NP: non-protected areas; PA: protected areas; N2000: Natura 2000 network. Distribución de los valores estimados de $\beta_{\text {ratio }}$ (sne/sor ratio) para conjuntos de especies presentes en cada red de áreas protegidas (PA and PA + N2000, respectivamente) y las especies presentes en un número equivalente de localidades NP seleccionadas al azar. NP: áreas no protegidas; PA: áreas protegidas; N2000: red Natura 2000. 
resenting the different components of aquatic diversity than non-protected or just randomly selected sites, especially for $\alpha$ and $\beta$-diversities. Only the $\gamma$-diversity was significantly greater in both protected area networks, especially when considering N2000. Generally, these results agree with previous studies showing some weaknesses in the capacity of protected areas to provide aquatic biodiversity (e.g., Abellán et al., 2007; Sánchez-Fernández et al., 2013; Guareschi et al., 2012; 2015a).

The analysis of the $\alpha$-diversity showed that localities within both protected area networks tend to gather a higher species richness of water beetles than those localities outside of protected areas, but without clear statistical support. There are different factors that might be related to this pattern: a) considering that the criteria to designate protected areas are often unrelated with aquatic biodiversity, reserves may contain many aquatic environments that show no particularly rich macroinvertebrate communities; b) it might be possible that non-protected sites exposed to low human intensity, as those in some midmountain areas, present a high species richness (Sánchez-Fernández et al., 2004; Millán et al., 2006; Abellán et al., 2007); and c) it is also true that the N2000 network includes habitats that represent different taxonomic singularities, rare or threatened in a European context, rather than cover the most diverse or richest sites (Guareschi et al., 2015a). In this sense, some naturally stressed habitats, several included in N2000 (Sánchez-Fernández et al., 2008a) such as saline environments (Millán et al. 2011), display low species richness (Gutiérrez-Cánovas et al., 2013) but most of them have a high ecological and conservation interest (Moreno et al., 1997). On the contrary, water surplus from irrigation crops can diminish the stress of salinity in mineralized streams not included in protected areas, facilitating the increase of species richness at the expense of the aforementioned most rare or singular species (Millán et al., 2011). In any case, it should be noted that a high local diversity in a given site does not necessarily indicate high conservation value.

Concerning the $\beta$-diversity and its components, spatial turnover was responsible for the most $\beta$-diversity among the protected sites, with only a small contribution from nestedness. Species composition changes within protected area networks are related to strong species replacement among sites. A similar pattern has recently been observed at the Iberian scale, where spatial turnover seems to be the main component of the total $\beta$-diversity in protected areas designated through national and regional laws (Guareschi
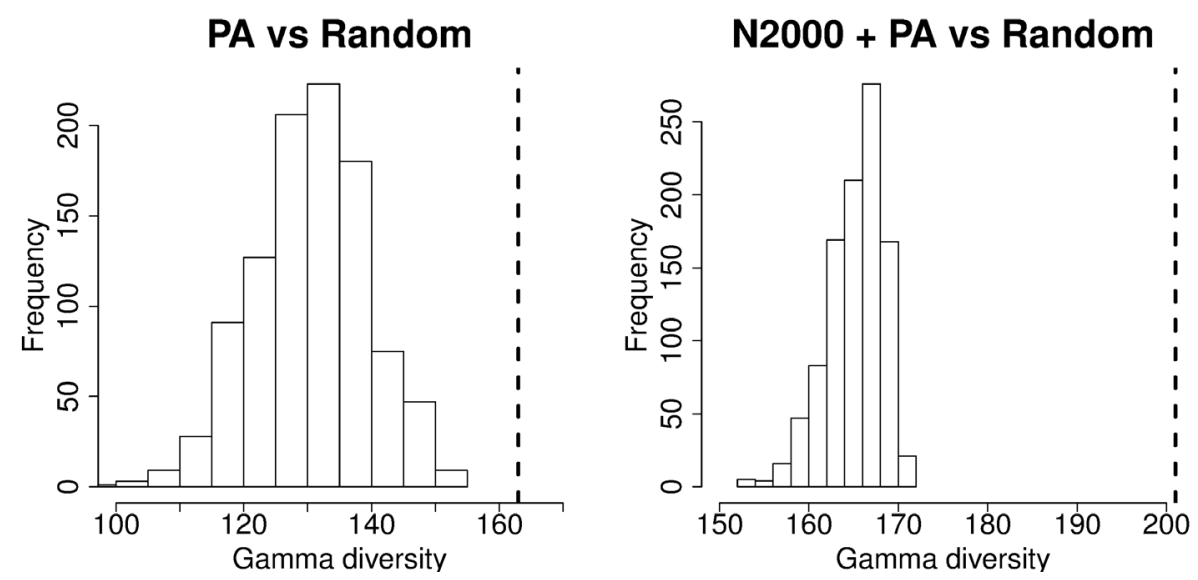

Figure 5. Comparison of the observed values of the $\gamma$-diversity (dashed line) in sites within protected areas networks (left, PA; right, $\mathrm{PA}+\mathrm{N} 2000)$ and in an equivalent number of sites selected randomly.NP: non-protected areas; PA: protected areas; N2000: Natura 2000 network. Comparación de los valores observados de la diversidad $\gamma$ (líneas discontinuas) en sitios dentro de áreas protegidas (izquierda, PA; derecha, PA + N2000) y en un conjunto equivalente de sitios seleccionados al azar. NP: áreas no protegidas; PA: áreas protegidas; N2000: red Natura 2000. 
et al., 2015a). In this sense, some other studies performed in the Segura River Basin demonstrated the existence of a strong altitudinal, climatic, geological and land use gradient (Millán $e t$ al., 1996, 2006; Díaz et al., 2008), which can be associated with species turnover between sites. More importantly, the $\beta$-diversity and its components were not always significantly different from random chance (i.e., communities in protected areas show $\beta$-diversity patterns that are indistinguishable from those arising from a random draw of an equivalent number of sites). The fact that the turnover in protected areas is not higher than expected by chance suggests a similar environmental complexity (Anderson et al., 2011; Heino et al., 2015) within and outside protected areas. Therefore, N2000 seems not to increase the diversity of habitats within the protected network, at least within the study area. Despite these general results, when the performance of PA and PA + N2000 were compared, it seems that including N2000 in the PA network could improve the capacity of protected areas to gather more aquatic biodiversity from non-protected areas.

When we focus on the $\gamma$-diversity, protected area networks capture a large proportion of the water beetle species pool of the Segura River Basin $(77.25 \%$ for PA and $95.26 \%$ for PA + N2000, respectively). Importantly, the overall species richness included in both protected area networks was significantly higher than expected by chance in networks of similar size, despite the fact that they were established with little consideration of their freshwater biodiversity (Morillo \& Gomez-Campo, 2000). Thus, the vast majority of the species from the Segura River Basin (201 of 211) have at least one population within the protected areas (see also Abellán et al., 2007). It is also remarkable that the ten species that are not included are neither endemic nor threatened in a local or national context (Sánchez-Fernández et al., 2004; 2008a; Abellán et al., 2005), despite their regional rarity. The significantly greater species pool found in protected areas provides some value to the role of protected networks in representing aquatic biodiversity. The higher number of species found in the combined network (PA + N2000) may also reflect the different, but complementary, criteria used to designate the priority areas (Abellán et al., 2007; Sánchez-Fernández et al., 2013; Guareschi et al., 2015a), where habitat representativeness plus species richness seems to be a crucial factor for gathering more global biodiversity. The greater number of covered species in the PA + N2000 network seems to be not just a result of the increase in protected land area, as the percentage of species within this network significantly differs from random expectations. Hence, when we address the role of the N2000 in protecting regional aquatic biodiversity, it seems that this network is an important complement to the PA network. Furthermore, in many cases, N2000 can also function as a buffer or transition area between pristine and humanized landscapes due to its large area and the suppression of the most intensive uses within the area (e.g., Sánchez-Fernández et al., 2013).

Nevertheless, it is worth noting that the presence of a particular taxon in a protected area does not guarantee its future persistence (Abellán et al., 2013; Sánchez-Fernández et al., 2013). The target biological groups for the designation of protected areas in N2000 are mostly vertebrates (birds and mammals) and higher plants, regardless of the relevance of other less charismatic groups, such as macroinvertebrates (e.g., Guareschi et al., 2015b). Thus, it is expected that although a great deal of the community of water beetles are included in the PA and N2000 networks, the management measures proposed might be inadequate to preserve aquatic biodiversity (Millán et al., 2012; Guareschi et al., 2015a). Furthermore, in the Segura River Basin, few protected areas have been created specifically to preserve the aquatic biota of inland waters (Abellán et al., 2007) because most of them are represented by headwater streams or springs in forest ecosystems. Thus, key sites for certain rare species of water beetles, such as some saline ecosystems, have not received protection (Sánchez-Fernández et al., 2008a). Only coastal wetlands, despite their deterioration (e.g., Ortega et al., 2004), are mostly protected to preserve waterbird populations. Moreover, the criteria for the designation of such protected areas do not con- 
sider important aspects related to the integrity of the entire basin, hydrological features or the ecological processes that maintain biodiversity (Skelton et al.,1995; Moyle \& Randall, 1998; Salomon et al., 2006; Belmar et al., 2013). Hence, the designation of special protection figures for inland waters (fluvial reserves) or aquatic invertebrates (micro-reserves) could foster the conservation of certain waterbodies, especially for those less represented in the PA or N2000 networks (Sánchez-Fernández et al., 2008a; Millán et al., 2011). Similarly, the use of watersheds as management and functional units seems essential for the coherent and adequate conservation of the aquatic ecosystems within protected areas (Millán et al., 2006; Abellán et al., 2007).

Our results are still robust despite the consideration of the high heterogeneity of the NP sites with respect to their ecological integrity. Including low diversity, degraded localities did not result in finding lower $\alpha$-diversity or a high weight of the nestedness component when comparing PA and NP areas. On the other hand, the fact that some of these sites included within NP areas may show good ecological status and diverse communities, reinforces the idea that the criteria used to select protected areas may be skewed towards terrestrial environments with charismatic vertebrates or plants. Given that both the $\alpha$ and $\beta$-diversities were indistinguishable from random expectations that included NP sites, managers should consider such well-preserved sites as good candidates to be included in the protected area network.

Overall, this study represents an important contribution to the determination of the effectiveness of protected areas in representing the aquatic biodiversity of the Segura River Basin and is a good complement for previous works (e.g., Sánchez-Fernández et al., 2004; Millán et al., 2006; Abellán et al., 2007) that are trying to achieve a better understanding of the presence and distribution of such biodiversity within the network of protected areas. The use of species diversity and its resultant components (Baselga, 2010) on water beetles as a biodiversity surrogate (Sánchez-Fernández et al., 2006; Bilton et al., 2006; Picazo et al., 2010; Guareschi et al., 2012) also constitutes a very interesting tool that can easily provide more precise information on the remaining biodiversity at different spatial scales in order to improve the design and management of the current and future networks of protected areas.

\section{ACKNOWLEDGEMENTS}

The authors would like to thank all of the members of the 'Ecología Acuática' Research Group (University of Murcia, Spain) for their help in collecting water beetle samples across the Segura River Basin, and especially to J. Velasco for her comments on an early version of the manuscript. C.G-C. is supported by the MARS project (Managing Aquatic ecosystems and water resources under multiple stress), which is funded by the European Union under the 7th Framework Programme, contract no. 603378. We would like to thank the two anonymous reviewers for their helpful comments on an earlier version of this manuscript.

\section{REFERENCES}

ABELLÁN, P., D. SÁNCHEZ-FERNÁNDEZ, J. VELASCO \& A. MILLÁN. 2005. Assessing conservation priorities for insects: status of water beetles in southeast Spain. Biological Conservation, 121: 79-90.

ABELLÁN, P., D. SÁNCHEZ-FERNÁNDEZ, J. VELASCO \& A. MILLÁN. 2007. Effectiveness of protected area networks in representing freshwater biodiversity: the case of a Mediterranean river basin (SE Spain). Aquatic Conservation: Marine and Freshwater Ecosystems, 17: 361-374.

ABELLÁN, P. \& J. C. SVENNING. 2013. Refugia within refugia-patterns in endemism and genetic divergence are linked to Late Quaternary climate stability in the Iberian Peninsula. Biological Journal of the Linnean Society, 113(1): 13-28.

ABELLÁN, P., D. SÁNCHEZ-FERNÁNDEZ, F. PICAZO, A. MILLÁN, J. M. LOBO \& I. RIBERA. 2013. Preserving the evolutionary history of freshwater biota in Iberian National Parks. Biological Conservation, 162: 116-126. 
ANDERSON, M. J., T. O. CRIST, J. M. CHASE, M. VELLEND, B. D. INOUYE, A. L. FREESTONE, N. J. SANDERS, H. V. CORNELL, L. S. COMITA, K. F. DAVIES, S. P. HARRISON, N. J. KRAFT, J. C. STEGEN \& N. G. SWENSON. 2011. Navigating the multiple meanings of $b$ diversity: a roadmap for the practicing ecologist. Ecology Letters, 14: 19-28.

BAILAN, E. V., H. SEGERS, K. MARTENS \& C. LEVÊQUE. 2008. An introduction to the freshwater animal diversity assessment (FADA) project. Hydrobiologia, 595(1): 3-8.

BASELGA, A. 2010. Partitioning the turnover and nestedness components of beta diversity. Global Ecology and Biogeography, 19: 134-143.

BASELGA, A. \& C. D. L. ORME. 2012. betapart: an $\mathrm{R}$ package for the study of beta diversity. Methods in Ecology and Evolution, 3: 808-812.

BELMAR, O., D. BRUNO, F. MARTÍNEZ-CAPEL, J. BARQUÍN \& J. VELASCO. 2013. Effects of flow regime alteration on fluvial hábitats and riparian quality in a semiarid Mediterranean basin. Ecological Indicators, 30: 52-64.

BILTON, D. T., L. MCABENDROTH, A. BEDFORD \& P. M. RAMSAY. 2006. How wide to cast the net? Cross-taxon congruence of species richness, community similarity and indicator taxa in ponds. Freshwater Biology, 51: 578-590.

BONADA, N., N. PRAT, V. H. RESH, \& B. STATZNER. 2006. Developments in aquatic insect biomonitoring: a comparative analysis of recent approaches. Annual Review of Entomology, 51, 495523.

BRUNO, D., D. SÁNCHEZ-FERNÁNDEZ, J. A. CARBONELL, F. PICAZO, J. VELASCO \& A. MILLÁN. 2012. Predicting aquatic insects richness in a semi-arid Mediterranean region. Limnetica, 31(1): 23-36.

BRUNO, D., O. BELMAR, D. SÁNCHEZFERNÁNDEZ, S. GUARESCHI, A. MILLÁN \& J. VELASCO. 2014. Responses of Mediterranean aquatic and riparian communities to human pressures at different spatial scales. Ecological Indicators, 45: 456-464.

DÍAZ, A. M., M. L. S. ALONSO, \& M. R. V. A. GUTIÉRREZ. 2008. Biological traits of stream macroinvertebrates from a semiarid catchment: patterns along complex environmental gradients. Freshwater Biology, 53: 1-21.
GEIST, J. 2011. Integrative freshwater ecology and biodiversity conservation. Ecological Indicators, 11: 1507-1516.

GESSNER, M. O., E. CHAUVET \& M. DOBSON. 1999. A Perspective on Leaf Litter Breakdown in Streams. Oikos, 85(2): 377-384.

GUARESCHI, S., C. GUTIÉRREZ-CÁNOVAS, F. PICAZO, D. SÁNCHEZ-FERNÁNDEZ, P. ABELLÁN, J. VELASCO \& A. MILLÁN. 2012. Macroinvertebrate biodiversity: patterns and surrogates in mountainous Spanish national parks. Aquatic Conservation: Marine and Freshwater Ecosystems, 22(5): 598-615.

GUARESCHI, S., D. T. BILTON, J. VELASCO, A. MILLÁN \& P. ABELLÁN. 2015a. How well do protected area networks support taxonomic and functional diversity in non-target taxa? The case of Iberian freshwaters. Biological Conservation, 187: 134-144.

GUARESCHI, S., P. ABELLÁN, A. LAINI, A. GREEN, J. A. SÁNCHEZ-ZAPATA, J. VELASCO, J. \& A. MILLÁN. 2015b. Cross-taxon congruence in wetlands: assessing the value of waterbirds as surrogates of macroinvertebrate biodiversity in Mediterranean Ramsar sites. Ecological Indicators, 49: 204-215.

GUTIÉRREZ-CÁNOVAS, C., A. MILLÁN, J. VELASCO, I. P. VAUGHAN \& S. J. ORMEROD. 2013. Contrasting effects of natural and anthropogenic stressors on beta-diversity in river organisms. Global Ecology and Biogeography, 22(7): 796-805.

HEINO, J., S. A. MELO \& L. M. BINI. 2015. Reconceptualising the beta diversity-environmental heterogeneity relationship in running water systems. Freshwater Biology, 60: 223-235.

HERBERICH, E., J. SIKORSKI \& T. HOTHOM. 2010. A robust procedure for comparing multiple means under heteroscedasticity in unbalanced designs. PLoS One, 5(3): p.e 9788.

HERBERT, M. E., P. B. MCINTYRE, P. J. DORAN, J. D. ALLAN \& R. ABELL. 2009. Terrestrial Reserve Networks Do Not Adequately Represent Aquatic Ecosystems. Conservation Biology, 24: 1002-1011.

JÄCH, M. A. \& M. BALKE. 2008. Global diversity of water beetles (Coleoptera) in freshwater. Hydrobiologia, 595: 419-442.

MILLÁN, A. 1991. Los Coleópteros Hydradephaga (Haliplidae, Gyrinidae, Noteridae y Dytiscidae) de la cuenca del río Segura (SE de la península 
Ibérica). Ph.D. Thesis. Universidad de Murcia, Spain.

MILLÁN, A., J. VELASCO, M. L. SUÁREZ, M. R. VIDAL-ABARCA \& L. RAMÍREZ-DÍAZ. 1996. Distribución espacial de los Adephaga acuáticos (COLEOPTERA) en la cuenca del río Segura (SE de la península Ibérica). Limnetica, 12(2): 13-79.

MILLÁN, A., P. ABELLÁN, I. RIBERA, D. SÁNCHEZ-FERNÁNDEZ \& J. VELASCO. 2006. The Hydradephaga of the Segura basin (SE Spain): twenty five years studying water beetles. Monograph on Hydroadephaga. In memoriam of Prof. Franciscolo. Memorie della Societá entomologica italiana, 85: 137-158.

MILLÁN, A., J. VELASCO, C. GUTIÉRREZ-CÁNOVAS, P. ARRIBAS, F. PICAZO, D. SÁNCHEZ-FERNÁNDEZ \& P. ABELLÁN. 2011. Mediterranean saline streams in southeast Spain: What do we know? Journal of Arid Environments, 75: 1352-1359.

MILLÁN, A., P. ABELLÁN, D. SÁNCHEZ-FERNÁNDEZ, F. PICAZO, J. VELASCO, J. M. LOBO \& I. RIBERA. 2012. Efectividad de la red de parques nacionales peninsulares en la protección de la biodiversidad acuática. En: Organismo Autónomo de Parques Nacionales (ed.): 151-181. Proyectos de Investigación en Parques Nacionales: 2008-2011. Madrid. MAGRAMA.

MILLÁN, A., D. SÁNCHEZ-FERNÁNDEZ, P. ABELLÁN, F. PICAZO, J.A. CARBONELL, J.M. LOBO \& I. RIBERA. 2014. Atlas de los coleópteros acuáticos de España peninsular. Ministerio de Agricultura, Alimentación y Medio Ambiente. Madrid.

MONROE, J. B., C.V. BAXTER, J. D. OLDEN \& P. L. ANGERMEIER. 2009. Freshwater in the public eye: understanding the role of images and media in aquatic conservation. Fisheries, 34: 581-585.

MORENO, J. L., A. MILLÁN, M. L. SUÁREZ, M. R. VIDAL-ABARCA \& J. VELASCO. 1997. Aquatic Coleoptera and Heteroptera assemblages in waterbodies from ephemeral coastal streams ("ramblas") of south-eastern Spain. Archiv für Hydrobiologie, 141(1): 93-107.

MORILLO, C. \& C. GÓMEZ-CAMPO. 2000. Conservation in Spain, 1980-2000. Biological Conservation, 95: 165-174.

MOYLE, P. B. \& P. J. RANDALL. 1998. Evaluating the biotic integrity of watersheds in the Sierra Nevada, California. Conservation Biology, 12: 1318-1326.
ODUM, E. P. \& G. W. WARRETT. 2006. Fundamentos de Ecología. México: Thomson.

ORMEROD, J. S., S. J. TYLER, S. J. PESTER \& A. V. CROSS. 1988. Censussing distribution and population of birds along upland rivers using measured ringing effort: a preliminary study. Ringing \& Migration, 9: 71-82.

ORTEGA, M., J. VELASCO, A. MILLÁN A \& C. GUERRERO. 2004. An ecological integrity index for littoral wetlands in agricultural catchments of Mediterranean semiarid regions. Environmental Management, 33(3): 412-430.

PEARSON, D. L. 1994. Selecting indicator taxa for the quantitative assessment of biodiversity. Philosophycal Transactions of the Royal Society, London Series B 345: 75-79.

PICAZO, F., D. SÁNCHEZ-FERNÁNDEZ, P. ABELLÁN, J. L. MORENO \& A. MILLÁN. 2010. Conservación de la biodiversidad en la provincia de Albacete: patrones e indicadores. Instituto de Estudios Albacetenses, Albacete.

PRENDA, J., M. CLAVERO, F. BLANCO-GARRIDO, A. MENOR \& V. HERMOSO. 2006. Threats to the conservation of biotic integrity in Iberian fluvial ecosystems. Limnetica, 25(1-2): 377-388.

QIAN, H., R. E. RICHLEFS \& P. S. WHITE. 2005. Beta diversity of angiosperms in temperate floras of eastern Asia and eastern North America. Ecology, 13: 179-193.

R DEVELOPMENT CORE TEAM. 2010. R:A Language and Environment for Statistical Computing. R Foundation for Statistical Computing, Vienna, Austria.

SALOMON, A. K., J. L. RUESINK \& R. E. DEWREEDE. 2006. Population viability, ecological processes and biodiversity: valuing sites for reserve selection. Biological Conservation, 128: 79-92.

SÁNCHEZ-FERNÁNDEZ, D., P. ABELLÁN, J. VELASCO \& A. MILLÁN. 2004. Selecting areas to protect the biodiversity of aquatic ecosystems in a semiarid Mediterranean region. Aquatic Conservation: Marine and Freshwater Ecosystems, 14: 465479.

SÁNCHEZ-FERNÁNDEZ,D., P. ABELLÁN, A. MELLADO, J. VELASCO \& A. MILLÁN. 2006. Are water beetles good indicators of biodiversity in Mediterranean aquatic ecosystems? The case of the Segura river basin (SE Spain). Biodiversity and Conservation, 15: 4507-4520. 
SÁNCHEZ-FERNÁNDEZ, D., D. T. BILTON, P. ABELLÁN, I. RIBERA \& A. MILLÁN. 2008a. Are the endemic water beetles of the Iberian Peninsula and the Balearic Islands effectively protected? Biological Conservation, 141: 1612-1627.

SÁNCHEZ-FERNÁNDEZ, D., J. M. LOBO, P. ABELLÁN, I. RIBERA \& A. MILLÁN. 2008b. Bias in freshwater biodiversity sampling: the case of Iberian water beetles. Diversity and Distributions, 14: 754-762.

SÁNCHEZ-FERNÁNDEZ, D., P. ABELLÁN, F. PICAZO, A. MILLÁN, I. RIBERA \& J. M. LOBO. 2013. Do protected areas represent species' optimal climatic conditions? A test using Iberian water beetles. Diversity and distributions, 19(11): 14071417.

SAUNDERS, D., J. MEEUWIG \& A. J. VINCENT. 2002. Freshwater protected areas: Strategies for conservation. Conservation Biology, 16: 30-41.

SKELTON, P. H., J. A. CAMBRAY, A. T. LOM-
BARD \& G. A. BENN. 1995. Patterns of distribution and conservation status of freshwater fishes in South Africa. South Africa Journal of Zoology, 30: 71-81.

STRAYER, D. \& D. DUDGEON. 2010. Freshwater biodiversity conservation: recent progress and future challenges. Journal of the North American Benthological Society, 29: 344-358.

ULRICH, W., ALMEIDA-NETO, M. \& GOTELLI N. J. 2009. A consumer's guide to nestedness analysis. Oikos, 118: 3-17.

VIDAL-ABARCA, M. R., M. L. SUÁREZ \& L. RAMÍREZ-DÍAZ. 1992. Ecology of Spanish semiarid streams. Limnetica, 8: 151-160.

WHITTAKER, R. H. 1960. Vegetation of the Siskiyou Mountains, Oregon and California. Ecological Monographs, 30: 279-338.

ZIMMER, A. 2010. New water uses in the Segura basin: conflicts around gated communities in Murcia. Water International, 35: 34-48. 